TRAMES, 2010, 14(64/59), 1, 21-33

\title{
THE EFFECT OF EDUCATION ON DIVORCE RISK IN ESTONIA
}

\section{Kadri Rootalu}

\author{
University of Tartu
}

\begin{abstract}
The impact of education on the risk of divorce has been demonstrated in numerous studies. At the same time, there is no consensus about the strength and the direction of this effect: do persons with a higher education have a higher or a lower risk of divorce? This study focuses on the direction and the strength of the effect of education on divorce in Estonia, using data from the longitudinal study "Paths of a Generation" (19832005). The educational level of both spouses is considered. The results indicate that people with higher educational levels have lower divorce risks. The protective effect of education is stronger for men than for women.
\end{abstract}

Keywords: divorce, education, life course, marriage, separation, Estonia

DOI: $10.3176 /$ tr.2010.1.02

\section{Introduction}

The trends in the rates of marriage dissolution have been a frequent topic of public discussion in Estonia since it regained independence in 1991. The number of divorces in Estonia was increasing until 1995, when (partly due to the new family law act passed in that year) the number of divorces per 100 marriages peaked at 106.4 (and the crude divorce rate reached 5.2). After that the crude divorce rate fell and has remained relatively stable since 2000 at about 3 until 2005 (Figure 1). This is still higher than in most other European countries. Estonia could be an interesting case for international comparison, as it is one of the least religious and least traditional countries in Europe in terms of family relations and forms (Kasearu 2008). This may have made divorce risk factors in Estonia different from those in other countries.

The aim of this analysis is to consider the impact of education on divorce risk in Estonia. To my knowledge, there are no recent studies of socio-demographic divorce risk factors in Estonia. The current article fills this gap. The data used for this purpose come from the longitudinal survey "Paths of a Generation" (Titma 


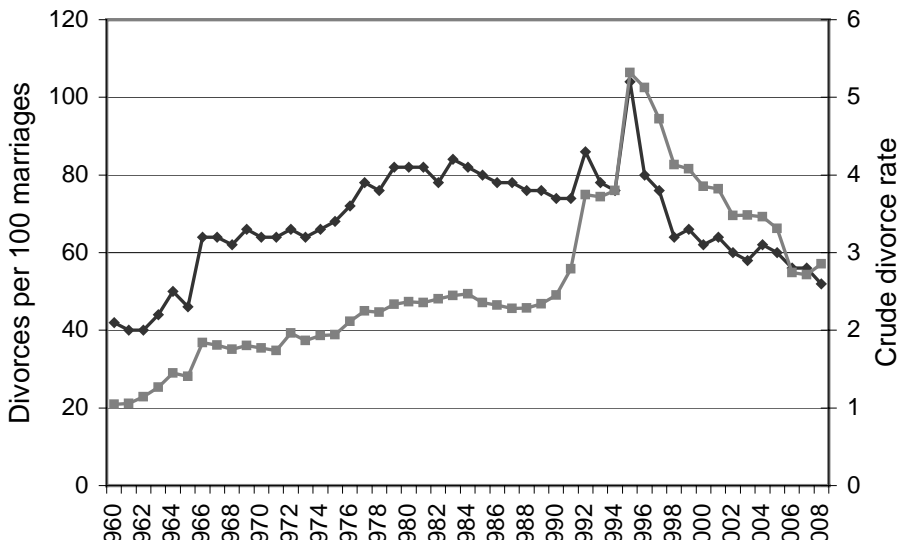

$\longrightarrow$ Crude divorce rate $\Longrightarrow-$ Divorces per 100 marriages

Figure 1. Divorce trends in Estonia (Data: Eurostat, Statistics Estonia)

and Tuma 1995). This study follows the life course of an educational cohort that graduated from the secondary school in 1983. The cohort is interesting because they started their independent life in the Soviet Union (before 1991) and experienced the regime change and the transition period as young adults.

\section{Education as a divorce risk factor}

There is no general agreement among researchers on the impact of education on the risk of divorce. The economic theory of the family predicts that the educational level of the wife should increase the risk of divorce (Becker et al. 1977). Better education gives women more economic opportunities outside the marriage and therefore makes the decision to leave the union easier. But as most of the married women in the Soviet Union participated in the labor force and did not stay at home until their children grew up, this explanation may not work in these circumstances. Therefore no strong impact of educational level of women on divorce risk should be anticipated in Estonia according to this explanation.

An important aspect of education is the potential to earn more in occupations that require higher education. This implies that people with higher education have more resources to handle divorce costs and therefore decide to divorce more easily.

On the other hand, researchers have argued that higher education may lower the divorce risk. The higher education of partners could mean that as they earn more, the family experiences less economic problems and this factor also should lower the divorce risk (Jalovaara 2003, Ono 1998, Oppenheimer 1997). But the high income of the wife may also increase the divorce risk, especially when the income of the wife is higher than the income of the husband (Jalovaara 2003). 
While the family income explanation of the impact of education on divorce has been tested several times in different studies, other perspectives have received less attention in the sociological study of divorce. For example, it has been stated that partners with higher educational levels could have better communication skills and therefore be able to solve conflicts in the family more easily (Amato 1996, Faust and McKibben 1999).

Another argument for the higher divorce risk of persons with higher education is that they hold more liberal values concerning divorce and accordingly may more easily decide to end an unsatisfactory union (Levinger 1979).

\subsection{Studies of educational impact on divorce}

The empirical evidence on the impact of education on divorce is mixed. The analysis of the data from the Fertility and Family Surveys by Härkönen and Dronkers (2006) did not find a relationship between education and divorce in most countries of Eastern and Northern Europe, including Estonia. The exceptions are Poland, where there is a positive impact of women's education on the divorce risk and Lithuania, where the relation is negative. Muszynska and Kulu (2007) show that dissolution levels do not differ across educational levels in Russia. Other studies of divorce in the Nordic countries mostly find a negative effect of education on divorce risk (Hoem 1997 for Sweden, Jalovaara 2003 for Finland, Lyngstad 2004 for Norway).

The reasons for the different directions of educational effects in different countries have not yet been examined thoroughly. One of the few studies is the comparative analysis by Härkönen and Dronkers (2006). They explain the variation with measures of the legal, social and economic environment of the countries. According to their study unconventional family practices (divorces, outof-wedlock births, and cohabitation) are associated with a negative and welfare state expenditures of the country with a positive educational gradient of divorce.

Michael and Tuma (1985) have found that the resources of the family of origin may influence the family formation process. These results suggest that the impact of parental education should be controlled in the current analysis. For example, Lyngstad (2004) has found a positive effect of parental education on the divorce risk of children in Norway. Possible explanations for this impact could be the more liberal upbringing of educated parents' children or more resources in the family of origin one can rely on in case of divorce.

\section{Other divorce risk factors}

Age at the start of the union has been shown to relate negatively to the divorce risk. Marriages where partners were very young at the start of the union have the highest risk of divorce (Bracher et al. 1993, Chan and Halpin 2005, Kiernan 1986, Lyngstad 2004, Martin and Bumpass 1989, Murphy 1985). Mostly the researchers 
point out three mechanisms of this relation. Firstly, people who marry young may be insufficiently mature to make complex decisions about the life of themselves, their partners and children (Booth \& Edwards 1985, Martin \& Bumpass 1989). Secondly, the partners who marry at young ages may develop in different directions during the time of marriage and may experience more dramatic life cycle transitions than people who marry at older ages (Morgan and Rindfuss 1985). And thirdly, the time for searching the suitable partner could have been insufficient and the decision to marry could have been hastened (Becker et al. 1977). Some researchers have also stressed the possibility that people who marry early may not have had adequate marital role models (Berrington and Diamond 1999, Booth and Edwards 1985, Bumpass and Sweet 1972).

Most studies show that cohabitations or marriages that started as cohabitations have a higher risk of separation than registered marriages (Axinn and Thornton 1992, Bennett et al. 1988, Berrington and Diamond 1999, Böheim and Ermish 2001, Bumpass and Lu 2000, Chan and Halpin 2005, White 1990). A possible explanation is that people who cohabit are less committed to the marriage than people who live in registered marriages (Axinn and Thornton 1992, Bennett et al. 1988, Smock 2000). Lillard et al. (1995) suggest a self-selection explanation: people who cohabit may hold more liberal values towards family and therefore may also divorce more easily.

Children are mostly considered a stabilizing factor in the marriage (Andersson 1997, Bracher et al. 1993, Lyngstad 2004). The economic theory of the family states that own children are a relation-specific investment that parents do not want to lose (Becker et al. 1977). Levinger (1979) sees feelings towards dependent children as a barrier for leaving the union. At the same time, premarital births are positively related to the divorce risk (Andersson 1997, Bumpass and Sweet 1972, Martin and Bumpass 1989, Waite and Lillard 1991), although Waite and Lillard (1991) found that the impact of premarital children is present only in the first years of marriages.

In recent years some researchers have reported that the number of children in the family could also increase the divorce risk. Böheim and Ermisch (2001) and Chan and Halpin (2005) found this in British data from the 1990s.

Some studies in Europe and many studies in North America showed that parental divorce during childhood may have a positive effect on the divorce risk of the children (Amato 1996, Bumpass and Sweet 1972, Diekmann and Engelhardt 1999, McLanahan and Bumpass 1988, Mueller and Pope 1977). Yet Wolfinger (1999) states that this effect decreased as divorces became more common. This suggests that the relationship between parental divorce and respondents' own divorce should not be strong in Estonia because the number of divorces was relatively high already when the generation under consideration was growing up. 


\section{Data and methods}

\subsection{Data}

The data used for this analysis come from the study "Paths of a Generation" (Titma and Tuma 1995). This is a longitudinal survey started in 1983, when a representative sample of students standing to graduate from secondary school in Estonia was interviewed. The respondents came from three types of secondary schools: general secondary schools, vocational schools and specialized secondary schools (see Titma and Saar 1995 for a detailed description of the school types in the analysis). About $25 \%$ of the respondents were graduates of specialized secondary schools and about $21 \%$ of vocational schools. As secondary education was compulsory at that time, the number of young people not represented by the current sample is small.

After 1983, four waves of interviews followed in the years 1987, 1992, 1997 and 2004. During the first two waves Estonia belonged to the Soviet Union. The students were born about 1965, which means that they lived in the Soviet Union until about the age of 25. Estonia regained independence in 1991 and the last three waves were conducted in independent Estonia. The data provide information about the life course of the original respondents until about the age of 40.

Longitudinal studies such as "Paths of a Generation" are most appropriate for studying sensitive topics like family events, including divorces. As they collect information on recent life events, the likelihood of inaccurate answers is lower than in retrospective studies. The other advantage of longitudinal studies is that, unlike national statistics, they can reflect cohabitations and separations

For the current analysis, information about the date of first marriage, divorce and childbirth, as well as other characteristics of respondents and their partners originates from the three last waves of interviews. Information from the interviews of the nearest waves to the events is used. Information about the parents of the respondents and from the situation in the parental family originates mostly from the first and third but also from the fourth and fifth wave of the interviews.

We have data on family events for 2329 persons. 92\% of them have been married or cohabiting. $81 \%$ of the first unions were registered marriages, the rest were cohabitations (Table 1). The mean age at the start of the first union was 23.1 years. This means that most of the respondents had first married during the Soviet period. Early first marriage is typical of that time. According to official statistics, the mean age at first marriage was 24.8 years for men and 22.8 years for women in 1988 (Statistics Estonia). Various reasons for such early marriage can be brought out. First, the age at marriage was low also in the generation of the parents of the respondents. For example, the mean age of marriage was 25.6 for men and 23.5 for women in 1970. Second, the Soviet job placement system could have played a role. Graduates were assigned to jobs where they were required to stay for a certain number of years. University committees who made the assignments took the marital status of the student into account. If a person was cohabiting, the assignment could separate him/her from his/her partner. The fact that a person was 
Table 1. Descriptive statistics for variables in the analysis

\begin{tabular}{|c|c|}
\hline & $\%$ \\
\hline Gender $^{1}$ : male & 44.3 \\
\hline Nationality $^{1}$ : Estonian & 80.2 \\
\hline Child in the family (before divorce) ${ }^{1}$ & 87.4 \\
\hline \multicolumn{2}{|l|}{ Education of the respondent ${ }^{1}$} \\
\hline General secondary & 11.2 \\
\hline Vocational, specialized secondary or some higher & 62.4 \\
\hline Higher & 26.4 \\
\hline Interrupted the studies ${ }^{2}$ & 13.4 \\
\hline Parent(s) higher education ${ }^{3}$ & 23.0 \\
\hline \multicolumn{2}{|l|}{ Education of the couple } \\
\hline \multicolumn{2}{|l|}{ Education of the husband ${ }^{4}$} \\
\hline Lower than general secondary & 3.1 \\
\hline General secondary & 18.4 \\
\hline Vocational & 58.1 \\
\hline Higher & 20.4 \\
\hline \multicolumn{2}{|l|}{ Education of the wife ${ }^{4}$} \\
\hline Lower than general secondary & 1.8 \\
\hline General secondary & 17.1 \\
\hline Vocational & 52.7 \\
\hline Higher & 28.4 \\
\hline Divorced or separated $^{1}$ & 23.2 \\
\hline Partner died 1 & 1.0 \\
\hline Parents divorced by the age of 16 (of the respondent) ${ }^{5}$ & 18.1 \\
\hline \multicolumn{2}{|l|}{${ }^{1} 2132$ cases } \\
\hline \multicolumn{2}{|l|}{2119 cases } \\
\hline \multicolumn{2}{|l|}{2086 cases } \\
\hline \multicolumn{2}{|l|}{${ }^{4} 1911$ cases } \\
\hline 1466 cases & \\
\hline
\end{tabular}

married usually ensured that the couple could work in the same city or region. This means that people often married just before graduation. The distribution of housing through the workplace according to the size of the family could have also influenced the age at marriage and at birth of the first child.

$23 \%$ of the respondents who have been married or living together with someone have divorced or separated and $1 \%$ have been widowed. The mean duration of the first union is 11.6 years (SD 5.8 years), censored observations taken into account, and the mean duration of a divorced union is 5.8 years (SD 4.4 years). The dates of marriage or start of cohabitation and the dates of possible marital dissolution or separation are available for 2132 respondents.

$85 \%$ of the respondents have at least one child and the mean age at the birth of the first child is 23.9 years. Twelve percent of the respondents had children before the first marriage and $40 \%$ had children less than six months into the first marriage (or start of cohabitation).

The dependent variable, the length of the first union, is measured in years from the date of the first marriage or from the start of first cohabitation until the 
dissolution or the last interview. The main independent variable in the analysis is the educational level of the respondents at the last wave of interviews. It is coded in three categories: general secondary, vocational or some higher education, and higher education (Table 1). Earlier analyses with the same data indicate that people with incomplete higher education may form a very specific (although small) educational group. In some waves of interviews this group was incorporated in a bigger group of specialized secondary education or incomplete higher education because of the similar number of study-years. So an additional variable was computed if the person terminated his or her studies in some educational institution.

Other variables include type of the union (registered marriage or cohabitation), age at the start of the union, presence of children in the family, gender, ethnicity (Estonian or non-Estonian, the latter mainly Russian-speaking), parental divorce (whether the parents were divorced when the respondent was 16), parental education (whether at least one parent had higher education). The educational level of the partner was obtained from the interviews of the respondents and is used in the analyses together with the educational level of the respondent.

\subsection{Methods}

This analysis uses the Sickle regression by Diekmann and Mitter (1984). The method estimates the risk of divorce by modeling the duration of marriage:

$$
r(t)=c t e^{-t / \lambda}
$$

where

$$
c=a_{0} a_{1}^{x_{1}} a_{2}^{x_{2}} \ldots a_{m}^{x_{m}} .
$$

In this model $x_{1}, \ldots x_{m}$ are covariates; $\lambda$ and $a_{o}, \ldots a_{m}$ are parameters to be estimated. The parameter $\lambda$ can be interpreted as the marriage duration until the maximum divorce risk. The value $\left(a_{k}-1\right) \times 100$ is the percentage change in divorce risk associated with one unit change in the independent variable.

The time-dependent variable of "presence of children in the family" was computed with the method of episode splitting (see Blossfeld and Rohwer 2002). Episode splitting means that the duration of the union was split into two records: marriage without children and marriage with children. If the respondent had children before marriage or if the respondent divorced before the birth of children there is only one record per person. Cox regression models were also built but are not reported since the results were similar and Sickle models provided a better fit. 


\section{Results}

The results for the risk of dissolution of the first union are shown in Table 2. The $\lambda$ coefficients in models $1-4$ indicate that the point with a maximum risk of divorce is approximately four years after the start of the union. These coefficients are robust to the inclusion and exclusion of independent variables in different models.

The modeling strategy is the following: first a model with the educational level and two control variables was estimated (model 1). Then other union-specific and educational variables were added (model 2). After that indicators of the type and starting time of the first union are excluded (model 3). The last model (model 4) examines the educational levels of both partners.

The results show that family events, such as age at first marriage, type of the union or presence of children in the family significantly affect the risk of divorce. Age at the start of the union has a negative effect on divorce risk. One additional

Table 2. Exponentiated coefficients from the Sickle regression model of divorce risk

\begin{tabular}{|c|c|c|c|c|}
\hline & Model 1 & Model 2 & Model 3 & Model 4 \\
\hline Gender: female & $1.56^{* * * *}$ & $1.31 * *$ & $1.60 * * *$ & $1.63^{* * *}$ \\
\hline Nationality: Estonian & $0.80 *$ & $0.79 *$ & $0.82+$ & $0.76^{*}$ \\
\hline Age at the start of the union & & $0.87 * * *$ & & $0.88 * * *$ \\
\hline Type of the union: registered marriage & & $0.51 * * *$ & & $0.64 * *$ \\
\hline Child in the family (before divorce) & & $0.44 * * *$ & $0.39 * * *$ & $0.50 * * *$ \\
\hline \multicolumn{5}{|l|}{ Education $^{1}$} \\
\hline General secondary & 1.17 & 1.04 & 1.31 & \\
\hline Vocational or some higher education & $1.26^{*}$ & 1.17 & $1.46^{* *}$ & \\
\hline Has interrupted the studies & & $1.26+$ & $1.26+$ & \\
\hline \multicolumn{5}{|l|}{ One (or both) of the parents has higher } \\
\hline \multicolumn{5}{|l|}{$\begin{array}{l}\text { Education of the male respondent or the } \\
\text { husband }^{1}\end{array}$} \\
\hline Lower than general secondary & & & & $2.45^{* *}$ \\
\hline General secondary education & & & & $1.79 * * *$ \\
\hline Vocational education or some higher & & & & $1.49 *$ \\
\hline \multicolumn{5}{|l|}{$\begin{array}{l}\text { Education of the female respondent or } \\
\text { the wife }^{1}\end{array}$} \\
\hline Lower than general secondary & & & & $3.97 * * *$ \\
\hline General secondary education & & & & 1.10 \\
\hline Vocational education or some higher & & & & 1 \\
\hline Constant $\alpha_{0}$ & $0.02 * * *$ & 1.24 & $0.02 * * *$ & $0.34+$ \\
\hline Constant $\lambda$ & $3.78 * * *$ & $4.12 * * *$ & $4.25^{* * *}$ & $4.55^{* * *}$ \\
\hline Log-likelihood & -2311.3 & -2234.7 & -2271.6 & -2270.7 \\
\hline
\end{tabular}

$+\mathrm{p}<0.1 ; * \mathrm{p}<0.05 ; * * \mathrm{p}<0.01 ; * * * \mathrm{p}<0.001$

Values are (exponentiated) regression $(\alpha)$ coefficients.

The percentage effect of covariate on the divorce risk is $(\alpha-1) * 100$.

Number of episodes in models 1-3 is 3619, number of unions 2065.

Number of episodes in model 4 is 3306, number of unions 1911.

${ }^{1}$ Reference category for the educational level of the person is higher education. 
year of age decreases the risk of divorce by about $13 \%$ (Table 2, model 2). The magnitude of the effect is similar to that in other studies applying Sickle models, which report an effect of about 10\% (Diekmann and Engelhardt 1999, Diekmann and Schmidheiny 2001). But as the age at marriage was strongly determined by the timing of graduation, the stronger effect in Estonia is understandable.

Registered marriages are more stable than cohabitations, and unions with at least one child are more stable than unions without children. The risk of dissolution for respondents in a registered marriage is about half of that for cohabiting couples. Couples with children have a divorce risk of $44 \%$ compared to childless couples (model 2).

Estonians have a slightly lower divorce risk than non-Estonians. Parental divorce (by the age of 16 of the child) does not have a significant effect on divorce risk after the age at the first marriage and the educational level are taken into account and was therefore left out of the models.

In model 1, consisting only of the variable of education and two control variables (gender and nationality), some educational differences can be seen. People with vocational education or some higher education show $26 \%$ higher divorce risks than people with university education. The educational level does not have a significant impact on divorce risk in the model where the age at marriage is also controlled (model 2). But as the age at the start of the first union probably is affected by the educational career, another model (model 3) was built without the variables of marriage. In that model, the educational level has an impact on the risk of divorce. Respondents with higher education showed lowest divorce risks. The risk of divorce for a person with vocational education was $46 \%$ higher than the risk of divorce for a person with higher education. Persons who interrupted their studies have a 26\% higher risk of divorce in models 2 and 3. Parental higher education also has a small negative effect on divorce risk.

When the educational level of both partners is taken into account (model 4), we see much stronger educational effects than in the first three models. Model 4 shows that persons with an educational level lower than secondary (a small group consisting only of the spouses of respondents) have higher divorce risks in comparison to other categories. Both men and women with higher education show lowest divorce risks. Yet men with vocational education or with general secondary education have higher divorce risk than men with higher education. This effect is much weaker and not statistically significant for women. So the results suggest that in this generation of students the higher education of the husband protects couples from divorce, whereas the education of the wife does not significantly affect the divorce risk.

\section{Discussion}

This article examined the influence of major socio-demographic factors on the risk of divorce on one educational cohort from the Estonian "Paths of a Generation" study. The analysis focused on the impact of educational variables. It 
supported the results of Härkönen and Dronkers (2006), showing no impact of educational level on the risk of divorce when the age at the start of union was controlled. To account for the strong correlation between the educational level and the age at marriage in Soviet Estonia, the analysis controlled the effect of the age at marriage. The model without the age at marriage revealed a negative impact of the educational level on divorce risk.

Earlier studies have shown that understanding the impact of socio-economic characteristics on divorce risk requires considering characteristics of both spouses (Diekmann and Schmidheiny 2001, Jalovaara 2003, Lyngstad 2004). When the educational level of both spouses is considered, the risk of separation is lower for persons with a higher educational level. Furthermore, there are gender differences in the effect of education. Education protects men from divorce better than women. This result disagrees with Jalovaara (2003), who found a rather genderneutral effect. At the same time, the notion that the educational impact on divorce is weaker for women is in line with the findings from the Fertility and Family Survey reported by Härkönen and Dronkers (2006). The positive educational gradient of divorce for men in Estonia also supports the Härkönen and Dronkers explanation, that in countries with unconventional family practices (many divorces, out-of-wedlock births, cohabiting couples) the educational gradient of divorce is more negative.

The aspect that only the husband's educational level is connected to the risk of divorce suggests that although the occupational sphere during this time was open for both men and women, the family roles were still traditional. This could mean that men were still looking for wives with lower educational levels than themselves and vice versa, women wanted to marry upwardly. If educational homogamy would have been valued, the higher education of both partners would have been decreasing the divorce risk.

Another explanation for the difference in the educational gradient of divorce could be the gender wage gap in Estonia. Women's university education did not pay off as much as did men's university education. This would be the case for example when the professions which are chosen mainly by women and which require a university education, are paid less than similar professions occupied by men. In such a situation the income of the wife would contribute less to the overall household material position and also to the reduction of possible economic problems.

When proceeding from the hypothesis that persons with a university education should have lower divorce risks because of their better conflict resolution skills, one could say that maybe the university education improves conflict resolution skills or lowers conflict frequency only for men. There is some support for this explanation in the literature about the division of household tasks in the family. It has been shown that the marriages of people with higher education, especially when the husband has a higher education, are more stable because the household division of labor is more equal in these unions (Bianchi et al. 2000, Frisco and Williams 2003). 
Finally, the current study is based on data about one educational cohort from 1983. It does not consider the overall impact of post-communist transition in Estonia on divorce, because the flow of societal changes is correlated with the age and duration of the marriages in the current cohort. Understanding the degree to which this pattern of educational impact on divorce applies to different birth cohorts still requires more extensive studies.

\section{Acknowledgements}

I thank Mikk Titma for making available the data of the "Paths of Generation" survey and Liina-Mai Tooding and Denis Trapido for valuable comments. The data collection has been funded by the US National Science Foundation grants SBR-9710399, SBR-0115028, SES-01-15028 and by the grant 018178s01 of the Estonian Ministry of Education.

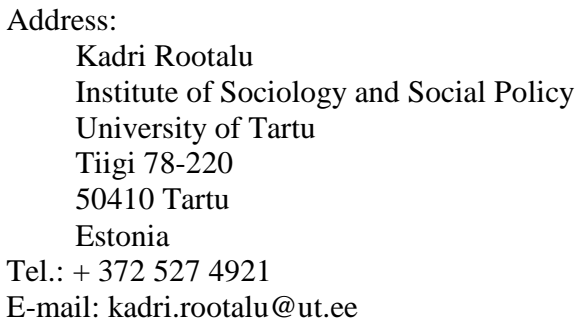

E-mail: kadri.rootalu@ut.ee

\section{References}

Amato, Paul R. (1996) "Explaining the intergenerational transmission of divorce". Journal of Marriage and the Family 58, 3, 628-640.

Andersson, Gunnar (1997) "The impact of children on divorce risks of Swedish women". European Journal of Population 13, 2, 109-145.

Axinn, William G. and Arland Thornton (1992) "The relationship between cohabitation and divorce: selectivity or causal influence?". Demography 29, 3, 357-374.

Becker, Gary S., Elizabeth M. Landes and Robert T. Michael (1977) "An economic analysis of marital instability”. Journal of Political Economy 85, 6, 1141-1187.

Bennett, Neil G., Ann Klimas Blanc and David E. Bloom (1988) "Commitment and the modern union: assessing the link between premarital cohabitation and subsequent marital stability". American Sociological Review 53, 1, 127-138.

Berrington, Ann and Ian Diamond (1999) "Marital dissolution among the 1958 British birth cohort: the role of cohabitation". Population Studies 53, 1, 19-38.

Bianchi, Suzanne M., Melissa A. Milkie, Liana C. Sayer and John P. Robinson (2000) "Is anyone doing the housework? Trends in the gender division of household labor". Social Forces 79, $1,191-228$.

Blossfeld, Hans-Peter and Götz Rohwer (2002) Techniques of event history modeling: new approaches to causal analysis. Mahwah: Lawrence Erlbaum.

Böheim, René and John Ermisch (2001) "Partnership dissolution in the UK - the rôle of economic circumstances". Oxford Bulletin of Economics and Statistics 63, 2, 197-208. 
Booth, Alan and John N. Edwards (1985) "Age at marriage and marital instability". Journal of Marriage and the Family 47, 1, 67-75.

Bracher, Michael, Gigi Santow, Philip S. Morgan and James Trussell (1993) "Marriage dissolution in Australia: models and explanations". Population Studies 47, 3, 403-425.

Bumpass, Larry L. and Hsien-Hen Lu (2000) "Trends in cohabitation and implications for children's family contexts in the United States". Population Studies 54, 1, 29-41.

Bumpass, Larry L. and James A. Sweet (1972) "Differentials in marital instability". American Sociological Review 37, 6, 754-766.

Chan, Tak Wing and Brendan Halpin (2005) "The instability of divorce risk factors in the UK". Working Paper Number 2005-06, Department of Sociology, University of Oxford, July, http://www.sociology.ox.ac.uk/swps/2005-06.pdf

Diekmann, Andreas and Henriette Engelhardt (1999) "The social inheritance of divorce: effects of parent's family type in postwar Germany”. American Sociological Review 64, 6, 783-793.

Diekmann, Andreas and Kurt Schmidheiny (2001) "Bildung und Ehestabilität: Eine Untersuchung schweizerischer Familienbiografien mit den Methoden der Ereignisanalyse". Swiss Journal of Sociology 27, 2, 241-254.

Diekmann, Andreas and Peter Mitter (1984) "A comparison of the "sickle function" with alternative stochastic models of divorce rates". In Stochastic modelling of social processes, 123-153. Andreas Diekmann and Peter Mitter, eds. Orlando: Academic Press.

Eurostat. (2007). Divorce indicators. Retrieved March 28, 2007, from http://epp.eurostat.ec.europa.eu

Faust, Kimberly A. and Jerome N. McKibben (1999) "Marital dissolution: divorce, separation, annulment, and widowhood". In Handbook of marriage and the family, 475-499. Marvin B. Sussmann, Suzanne K. Steinmetz, and Gary W. Peterson, eds. New York: Plenum Press.

Frisco, Michelle L. and Kristi Williams (2003) "Perceived housework equity, marital happiness, and divorce in dual-earner households". Journal of Family Issues 24, 1, 51-73.

Härkönen, Juho and Jaap Dronkers (2006) "Stability and change in the educational gradient of divorce: a comparison of seventeen countries". European Sociological Review 22, 5, 501517.

Hoem, Jan M. (1997) "Educational gradients in divorce risks in Sweden in recent decades". Population Studies 5, 1, 19-27.

Jalovaara, Marika (2003) "The joint effects of marriage partners' socioeconomic positions on the risk of divorce". Demography 40, 1, 67-81.

Kasearu, Kairi (2008) "Vaba kooselu Eestis ja Euroopas - kas eestlased eelistavad vaba kooselu abielule materiaalsetel põhjustel?" [Cohabitation in Estonia and Europe - do Estonians prefer cohabitation due to financial reasons?] Eesti Euroopa võrdlustes, 19-34. [Estonia in European comparisons] Mare Ainsaar and Dagmar Kutsar, eds. Series of the Ministry of Social Affairs 3.

Kiernan, Kathleen E. (1986) "Teenage marriage and marital breakdown: a longitudinal study". Population Studies 40, 1, 35-54.

Levinger, George (1979) “A social psychological perspective on marital dissolution”. In Divorce and separation, 37-63. George Levinger and Oliver C. Moles, eds. New York: Basic Books.

Lillard, Lee A., Michael J. Brien and Linda J. Waite (1995) "Premarital cohabitation and subsequent marital dissolution: a matter of self-selection?". Demography 32, 3, 437-457.

Lyngstad, Torkild Hovde. (2004) “The impact of parents' and spouses' education on divorce rates in Norway". Demographic Research 10, 121-142.

Martin, Teresa Castro and Larry L. Bumpass (1989) "Recent trends in marital disruption". Demography 26, 1, 37-51.

McLanahan, Sara and Larry L. Bumpass (1988) "Intergenerational consequences of family disruption”. American Journal of Sociology 94, 1, 130-152.

Michael, Robert T. and Nancy B. Tuma (1985) "Entry into marriage and parenthood by young men and women: the influence of family background". Demography 22, 4, 515-544.

Morgan, Philip S. and Ronald R. Rindfuss (1985) "Marital disruption: structural and temporal dimensions". The American Journal of Sociology 90, 5, 1055-1077. 
Mueller, Charles W. and Hallowell Pope (1977) "Marital instability: a study of its transmission between generations". Journal of Marriage and the Family 39, 1, 83-92.

Murphy, M. J. (1985) "Demographic and socio-economic influences on recent British marital breakdown patterns". Population Studies 39, 3, 441-460.

Muszynska, Magdalena.and Hill Kulu (2007) "Migration and union dissolution in a changing socioeconomic context: the case of Russia". Demographic Research 17, 803-820.

Ono, Hiromi (1998) 'Husbands' and wives' resources and marital dissolution". Journal of Marriage and the Family 60, 3, 674-689.

Oppenheimer, Valerie Kincade (1997) "Women's employment and the gain to marriage: the specialization and trading model". Annual Review of Sociology 23, 431-453.

Smock, Pamela J. (2000) "Cohabitation in the United States: an appraisal of research, themes, findings and implications". Annual Review of Sociology 26, 1-20.

Statistics Estonia. (2007). Population. Retrieved March 28, 2007, from http://pub.stat.ee/pxweb.2001/I_Databas/Population/Population.asp

Titma, M. and Ellu Saar (1995) "Regional differences in Soviet secondary education". European Sociological Review 11, 1, 37-58.

Titma, Mikk and Nancy B. Tuma (1995) Paths of a generation: a comparative longitudinal study of young adults in the former Soviet Union. Stanford and Tallinn.

Waite, Linda J. and Lee A. Lillard (1991) "Children and marital disruption". American Journal of Sociology 96, 4, 930-953.

White, Lynn K. (1990) "Determinants of divorce: a review of research in the eighties". Journal of Marriage and the Family 52, 4, 904-912.

Wolfinger, Nicholas H. (1999) "Trends in the intergenerational transmission of divorce". Demography 36, 3, 415-420. 